Отримано: 29 травня 2018 р.

Прорецензовано: 02 червня 2018 р.

Прийнято до друку: 05 червня 2018 р. e-mail: mira_may@ukr.net

DOI: $10.25264 / 2311-5149-2018-9(37)-98-102$
Бедринець М. Д. Бюджетна децентралізація як необхідна умова регіонального розвитку. Наукові записки Начіонального університету «Острозька академія». Серія «Економіка» : науковий журнал. Острог : Вид-во НаУОА, червень 2018. № 9(37). C. $98-102$.

Бедринець Мирослава Дмитрівна,

кандидат економічних наук, доцент,

Університет державної фіскальної служби Украӥни

\title{
БЮДЖЕТНА ДЕЦЕНТРАЛІЗАЦІЯ ЯК НЕОБХІДНА УМОВА РЕГІОНАЛЬНОГО РОЗВИТКУ
}

У статті розглянуто проблеми бюджетної децентралізації в Україні як необхідної умови регіонального розвитку. На основі вивчення цієї проблеми автор зробив висновок, щчо, якщчо розглядати бюджетну децентралізацію як прочес наповнення місцевих бюджетів завдяки перерозподілу податкових платежів, то такий підхід не приведе до реальних зрушень у регіональній економіці, не дасть можливості реально підвищити рівень життя населення регіонів. У статті обтрунтовано, що сьогодні має йтися не тільки про наповнення місчевого бюджету, а й про якість управління фінансами, у чому і розкривається справжній зміст децентралізації, а саме: у наділенні регіонів більшою свободою у використанні коштів, зібраних у вигляді місцевих податків, із метою підвищення рівня життя населення, розвитку регіональної економіки на основі ефективного використання ресурсів місиевого бюджету.

Ключові слова: децентралізація, бюджет, місчеве самоврядування, розвиток, ефективність.

\section{Бедринец Мирослава Дмитриевна,}

кандидат экономических наук, дочент,

Университет государственной фискальной службы Украинь

\section{БЮДЖЕТНАЯ ДЕЦЕНТРАЛИЗАЦИЯ КАК НЕОБХОДИМОЕ УСЛОВИЕ РЕГИОНАЛЬНОГО РАЗВИТИЯ}

В статье рассмотрены проблемы бюджетной децентрализачии в Украине как необходимого условия регионального развития. На основе изучения данной проблемы автором сделан вывод, что, если рассматривать бюджетную децентрализацию как процесс наполнения местных бюджетов за счет перераспределения налоговых платежей, то такой подход не приведет к реальным сдвигам в региональной экономике, не позволит реально повысить уровень жизни населения регионов. В статье обосновано, что сегодня речь должна идти не только о наполнении местного бюджета, но и о качестве управления финансами, в чем и раскрывается истинный смысл децентрализации, а именно: в наделении регионов большей свободой в использовании средств, собранных в виде местных налогов, с иелью повышение уровня жизни населения, развития региональной экономики на основе эффективного использования ресурсов местного бюджета.

Ключевые слова: децентрализация, бюджет, местное самоуправление, развитие, эффективность.

\section{Myroslava Bedrinets,}

PhD, associate professor,

National University of the State Fiscal Service of Ukraine

\section{BUDGET DECENTRALIZATION AS A NECESSARY CONDITION OF THE REGIONAL DEVELOPMENT}

The article considers the problems of budgetary decentralization in Ukraine as a necessary condition of the regional development. Based on the study of this problem, the author concludes that if one considers budget decentralization as a process of filling local budgets through the redistribution of tax payments, such an approach will not lead to real changes in the regional economy and will not enable to really improve the living standards of the regions. The article substantiates that today the question is not only about filling the local budget, but also about the quality of financial management, which reveals the true meaning of the decentralization, namely: giving the regions greater freedom to use funds collected in the form of local taxes in order to improvem living standards of the population, developm the regional economy on the basis of effective use of the local budget resources.

Key words: decentralization, budget, local government, development, efficiency.

Постановка проблеми. Актуальність теми дослідження обумовлена реальним посиленням процесу 
децентралізації державного управління в Україні та становленням дієвого інституту місцевого самоврядування, вдосконаленням механізмів взаємодії бюджетів різного рівня в межах єдиної бюджетної системи країни, розробкою стимулів до ефективної і відповідальної діяльності територіальних органів влади в бюджетно-податковій сфері.

Тому виникає необхідність дослідження проблем бюджетної децентралізації, розробки практичних рекомендацій щодо розвитку муніципальних фінансів в умовах політки децентралізації, що проводиться в Україні.

Аналіз останніх досліджень і публікацій. Наше дослідження базуються на положеннях про необхідність обгрунтованої бюджетної децентралізації, яка повинна спиратися на розширення фінансової свободи у прийнятті рішень і на підвищення рівня відповідальності органів місцевого самоврядування у бюджетній сфері, які сформульовані в роботах Дж. Уоллісома, В. Оутсома, Т. Занга, Х. Зоу, а також вітчизняних дослідників О. О. Молдована, Т. Сало, І. О. Луніної та ін.

У роботах цих авторів порушені питання децентралізації державного управління, насамперед, із погляду необхідності підвищення ефективності економіки. На основі теорії суспільного сектора і державних фінансів розробляють варіанти розвитку регіональних економік, їх фінансового забезпечення, зокрема на основі використання механізмів бюджетної децентралізації.

Мета статті - розглянути бюджетну децентралізацію як необхідну умову регіонального розвитку, завданням дослідження є розкриття справжнього змісту децентралізації, а саме: у наділенні регіонів із більшою свободою у використанні коштів.

Виклад основного матеріалу. Децентралізація сектору публічного управління та фінансів сьогодні $\epsilon$ одним із ключових чинників високої ефективності бюджетної системи. Цей процес відбувається не лише в федеральних країнах і країнах з історично впливовими позиціями місцевої влади, а й у країнах, що мають унітарний устрій, таких як Україна. Бюджетна децентралізація, як зазначає О. О. Молдован, не $\epsilon$ наслідком політико-історичних процесів, а більшою мірою її свідомо застосовують як механізм підвищення ефективності розподілу та використання бюджетних фондів [8].

Необхідно звернути увагу на те, що рішення проблеми бюджетної децентралізації в Україні $є$ частиною більш загальної проблеми забезпечення ефективного функціонування багаторівневої бюджетної системи, головне призначення якої полягає у створенні умов для ефективного і відповідального виконання органами влади всіх рівнів своїх функціональних повноважень у межах ресурсів відповідних бюджетів. Це означає, що в процесі бюджетної децентралізації мають бути створені умови для: - надання публічних благ відповідно до потреб і переваг місцевого населення («самоврядування створюється для того, щоб забезпечувати місцеві інтереси»); - підвищення відповідальності місцевих органів влади за виконання закріплених за ними функцій, а значить за ефективність витрат місцевих бюджетів; - збільшення видатків місцевих бюджетів залежно від зростання власних доходів і розвитку економіки відповідних територій [7].

Слід зазначити, що в теорії значний внесок у розвиток сучасних наукових уявлень про зміст бюджетної децентралізації належить англійському економісту В. Оутсу, який запропонував ії визначення: «Децентралізація - це право незалежного прийняття рішень децентралізованими одиницями» [13].

Сенс децентралізації полягає в тому, що регіональні та місцеві органи влади мають можливість самостійно приймати рішення з фінансових питань і питань з управління територією. Ще на самому початку розвитку цієї теорії, тридцять років тому, Дж. Уолліс і В. Оутс висунули положення про співвідношення централізації і децентралізації в державному управлінні. На думку цих дослідників, чим ширше країна за площею, тим менше централізованим при інших рівних умовах має бути державне управління (фактор територіі); чим більше чисельність населення країни, тим менше централізованим має бути державне управління (фактор щільності населення); чим вище частка населення, зосередженого в містах, тим менше централізованим має бути державне і регіональне управління (фактор соціальної інфраструктури); чим вище рівень доходу на душу населення, тим більше централізованим має бути державне управління та його участь у програмах, пов'язаних із перерозподілом доходів (фактор інвестиційної залежності держави від економіки); чим більш різноманітним є попит на державні послуги, що випливає 3 нерівномірного розподілу доходів по регіонах, тим менше централізованим при інших рівних умовах має бути управління з боку держави і регіонів (фактор соціальної залежності держави від економіки) [15].

Аналіз робіт [7; 10] показує, що дослідники не ставлять під сумнів той факт, що децентралізація в бюджетній сфері має переваги, які виявляються під час порівняння суспільних витрат і вигод.

Слід мати на увазі, що якщо децентралізація не впливає на рівень витрат, то децентралізоване управління або ефективніше централізованого, або, принаймні, не поступається йому з погляду ефективності. Децентралізація ефективна, якщо підвищення витрат перекривається виграшем.

Наукові записки Національного університету «Острозька академія», серія «Економіка», № 9(37), червень, 2018 р. 
Бюджетна децентралізація покликана вирішувати два основних завдання: по-перше, підвищувати алокаційну і продуктивну ефективність функціонування бюджетної системи. Завдяки децентралізації громадські послуги можна організувати і надавати так, щоб вони найбільш відповідали уподобанням місцевих жителів, тобто забезпечувати підвищення алокаційної ефективності, або якості розподілу наявних ресурсів між напрямами їх використання. Поряд із цим, децентралізація супроводжується і підвищенням продуктивності функціонування бюджетної системи, забезпечуючи підзвітність місцевої влади своєму населенню і скорочуючи число інстанцій, у яких доводиться погоджувати рішення, оскільки більше повноважень надається місцевим органам влади, які краще знають місцеву специфіку і місцеві потреби. Таким чином, децентралізація в широкому іiі розумінні передбачає передачу більш значних повноважень органам влади на місцях, із тим, щоб ті могли самостійно приймати рішення щодо формування доходів, витрат і нормативно-правового регулюванню. Місцева влада ближче до населення, краще знає його потреби і тому здатна задовольнити його потреби краще, ніж центральна влада. Близькість місцевої влади до населення також сприяє посиленню громадянської активності, підвищенню прозорості влади і посиленню іiі підконтрольності населенню.

По-друге, важливим аргументом на користь децентралізації є той факт, що різні суспільні блага мають неоднакове охоплення. Так, послугами 3 питань національної оборони користуються громадяни країни, а користь від внутрішніх водних шляхів або наявності лісу дістається лише жителям конкретних регіонів. Комунальні послуги - такі, як збір і вивезення сміття, вуличне освітлення і т. ін., адресовані жителям конкретних населених пунктів, і потреби в них будуть неоднаковими в різних регіонах. Оскільки центральний уряд не може врахувати таке розмаїття переваг у кожному регіоні або місцевості, виробництво різних суспільних благ має покладатися на різні рівні влади. Це означає, що за нижнім рівнем влади закріплюються всі податкові (прибуткові), видаткові повноваження та повноваження щодо нормативно-правового регулювання, за винятком тих повноважень, щодо яких можуть бути представлені переконливі докази того, що закріплення їх за самим нижнім рівнем влади неефективне. Надання суспільних благ тільки силами установ, підвідомчих центральному уряду, пов'язане зі значними витратами: при однаковому підході до всіх територій на одних територіях буде відбуватися перевиробництво суспільних благ, на інших - їх недовиробництво.

Важливою перевагою децентралізації $є$ також те, що адміністративна автономія створює передумови для навчання, пошуку нових підходів, підвищення загальної якості управління. Децентралізовані системи здатні забезпечити більшу стабільність, оскільки місцеві автономії обмежують можливості центру проводити фіскальну або монетарну політику на свій розсуд. Реальна децентралізація, що передбачає жорсткість бюджетних обмежень і виборність місцевих органів влади, призводить до зниження бюджетного дефіциту.

Нарешті, децентралізований процес прийняття рішень дозволяє оцінювати різні варіанти рішень, стимулюючи поширення передового досвіду. Водночас дуже важливо, щоб повноваження передавалися на той рівень, який реально здатний провести ті чи інші необхідні заходи і зацікавлений у їх результатах $[14 ; 16]$.

Чітка структуризація делегованих і власних повноважень органів місцевого самоврядування має супроводжуватися поступовим переходом від бюджетного забезпечення до бюджетного регулювання, спрямованого на підвищення самостійності місцевих органів у сфері податкової та кредитної політики [11].

Слід сказати, що наміри про бюджетну децентралізацію в Україні були оголошені в 1998 р., але вона не була комплексною та не супроводжувалася адміністративно-територіальною реформою.

Проблема децентралізації набула надзвичайної актуальності після 2014 р., коли питання реформ увійшли до порядку денного роботи парламенту та уряду, коли була підтверджена нежиттєздатність принципу демократичного централізму в організації державного управління [5].

У 2014 році в Україні була затверджена Концепція реформи місцевого самоврядування та територіальної організації влади в Україні, яка мала забезпечити створення належних матеріальних, фінансових та організаційних умов, а також формування кадрового складу для забезпечення виконання органами місцевого самоврядування власних і делегованих повноважень [4].

У тому ж році був прийнятий Закон України «Про внесення змін до Бюджетного кодексу України щодо реформи міжбюджетних відносин», який суттєво змінив фінансові потоки між державним і місцевими бюджетами на користь останніх [9].

Бюджети різних рівнів отримали тоді додатковий ресурс завдяки зміні правил сплати прибуткового податку, відрахування плати за адміністративні послуги до місцевих бюджетів; появи 5\% збору з роздрібних продажів; зміни пропорції відрахувань екологічного податку - $20 \%$ до держбюджету, $80 \%$ - до 
бюджетів інших рівнів; реформи податку на нерухомість (розширення бази оподаткування); відрахування до обласних бюджетів 10\% податку на прибуток, який раніше повністю надходив до держбюджету.

Крім того, місцеві бюджети отримали низку додаткових бонусів - право на свій розсуд вибирати банки для зберігання й обслуговування власних коштів, самостійно, без прив'язки до держбюджету, затверджувати свої кошториси [1].

За даними Кабінету Міністрів України в результаті реформи децентралізації влади було змінено систему фінансування та знайдено інструменти фінансування регіонального і місцевого розвитку, які дозволяють місцевій владі ефективно вирішувати проблеми на місцях і не допускати їх виникнення. У результаті цього кількість дотаційних місцевих бюджетів знизилась на 25\% [2].

Значно зросли обсяги доходів місцевих бюджетів. Так, за перше півріччя 2017 року надходження власних доходів загального фонду місцевих бюджетів України зросли на 34\%, порівняно 3 аналогічним періодом минулого року і склали 87 млрд. грн, що на 22 млрд. більше, ніж у 2016 році. У першому півріччі 2017 року доходи місцевих бюджетів об'єднаних територіальних громад збільшилися майже удвічі, склавши 3,9 млрд грн (+1,9 млрд). Із розрахунку на одного мешканця громади середній показник надходжень також зріс практично удвічі з 640 до 1256 грн (темп зростання - 196,2\%) [3].

Безумовно, що зміцнення фінансової бази регіонів слід оцінювати позитивно і дані результати - це значне досягнення українського уряду.

Однак, не дивлячись на те, що громади отримують увесь спектр повноважень і фінансових ресурсів, які формують умови для їх швидкого розвитку, істотних, кардинальних змін у житті регіонів не спостерігається. Це пов’язано з неготовністю місцевих органів влади управляти фінансами на новому рівні відповідальності, з тим, що така реформа не повною мірою вирішила проблеми розвитку українських регіонів на основі бюджетної децентралізації [5; 7].

Зазначимо, що емпіричні дослідження, у яких тестується зв'язок між економічним зростанням і міжбюджетними відносинами, присвячені переважно такому аспекту цих відносин, як ступінь фіскальної децентралізації. У дослідженні [12] модель зростання була доповнена державними витратами урядів різних рівнів і емпірично перевірена на вибірці розвинених країн і країн, що розвиваються. Водночас висунута авторами гіпотеза про те, що фіскальна децентралізація позитивно впливає на національний економічний ріст, не знайшла підтвердження. Висловлюється припущення, що до такого результату могло призвести неефективне управління фінансами, низька віддача від інвестицій, які місцева влада вкладає в розвиток регіональної економіки.

Звідси випливає висновок про необхідність подальшої роботи, спрямованої на вдосконалення механізму бюджетної децентралізації як необхідної умови регіонального розвитку щодо підвищення якості фінансовими ресурсами, які сьогодні виявляються в розпорядженні регіонів. У цьому контексті можна сформулювати такі положення, на яких слід вибудовувати систему місцевого оподаткування.

1. Податкові надходження повинні здебільшого покривати потреби місцевого бюджету. Водночас система місцевого оподаткування не повинна бути єдиним джерелом місцевого фінансового бюджету. Є багато інших способів вирішення проблем розвитку регіонів завдяки використанню прогресивних методів організації регіональної економіки (регіональні науково-виробничі кластери), співпраці місцевої влади і бізнесу у вирішенні проблем регіонального розвитку, випуск муніципальних цінних паперів тощо.

2. У регіонах необхідно активно впроваджувати методи програмно-цільового планування бюджету, що дасть можливість підвищити ефективність бюджетних витрат.

3. Забезпечення зростання доходів населення і відповідно задоволення його зростаючих потреб неможливо без встановлення відповідного контролю за використанням коштів місцевого бюджету з боку громади. Дослідники вказують, що контролювати витрати бюджету органів місцевого самоврядування повинні самі платники податків. Західні дослідники багато уваги приділяють питанням громадського контролю, який надає досить широкий набір інструментів і будується, насамперед, навколо принципів прозорості муніципальної влади й участі суспільства в їі формуванні. Такий контроль забезпечується також шляхом прийняття державою спеціальних нормативних актів про розкриття інформації, громадських слухань, голосування, петиції, експертиз, журналістських розслідувань. У результаті чиновники відчувають постійну увагу до їх діяльності з боку суспільства, що підвищує відповідальність за прийняті рішення, зростає ефективність використання коштів, що знаходяться в розпорядженні місцевих органів влади.

Безумовно, що такі напрями не вичерпують усього різноманіття можливих шляхів підвищення ефективності бюджетної децентралізації. Однак вони, на нашу думку, здатні вже найближчим часом підвищити якість такого процесу, реально сприяти вирішенню завдань, які пов'язані з використанням децентралізації в системі державного управління економікою і соціальним розвитком. 
Висновки. Підбиваючи підсумки, ще раз зазначимо на необхідність розвитку бюджетної децентралізації як необхідної умови регіонального розвитку. Водночас звернемо увагу на те, що якщо розглядати бюджетну децентралізацію винятково як процес наповнення місцевих бюджетів за рахунок перерозподілу податкових платежів, то такий підхід не приведе до реальних зрушень у регіональній економіці, не дасть можливості реально підвищити рівень життя населення регіонів.

Сьогодні йдеться не тільки про наповнення місцевого бюджету, а й про якість управління фінансами, в чому і розкривається справжній зміст децентралізації, а саме: у наділенні регіонів більшою свободою у використанні коштів, зібраних у вигляді місцевих податків, із метою підвищення рівня життя населення, розвитку регіональної економіки на основі ефективного використання ресурсів місцевого бюджету.

\section{Література:}

1. Бюджетная децентрализация: жизнь или смерть больших и малых украинских городов. Vox Ukraine. Режим доступу: https://petrimazepa. com/fiscaldecentralization.

2. Гройсман В. Кількість дотаційних бюджетів знизилась на 25 \%. TVi, 24 лютого 2017 року. - Режим доступу: http:/tvi.ua/novini/kilkist-dotacijnih-byudzhetiv-znizilas-na-25-grojsman.html.

3. Зубко Г. Місцеві бюджети за півроку збільшились. - Режим доступу: http://www.kmu.gov.ua/control/uk/ publish/article?art_id $=250115079 \&$ cat_id $=244276429$.

4. Концепція реформи місцевого самоврядування та територіальної організації влади в Україні: Розпорядження КМУ від 1 квітня 2014 р. № 333-p. - Режим доступу: http://zakon3.rada.gov.ua/laws/show/333-2014$\% \mathrm{D} 1 \% 80$.

5. Кузькін $Є$. Ю. Вплив децентралізації на розвиток регіонів // Наукові праці НДФІ - 2016 - № 3 (76). C. $39-53$.

6. Лунина И. А. Бюджетная децентрализация: цели инаправления реформ / И. А. Лунина // Экономика Украины. - 2014. - № 11. - С. 61-75.

7. Луніна І.О. Бюджетна децентралізація в Україні у контексті європейських тенденцій місцеві бюджети в умовах децентралізації // Збірник наукових праць Університету державної фіскальної служби України, № 2, 2016. - C. $155-171$.

8. Молдован О.О. Бюджетна децентралізація: досвід ефективної реформи Словаччини для України / О. О. Молдован // Вісник Донецького національного університету. - 2010. - С. 30-37.

9. Про внесення змін до Бюджетного кодексу України щодо реформи міжбюджетних відносин: Закон Украінн від 28.12.2014. - Режим доступу: http://zakon0.rada.gov.ua/laws/show/79-19.

10. Сало Т. В.Децентралізація фінансової системи: стан та оцінка рівня в Україні / Т. В. Сало // Ефективність державного управління. - 2013. - Вип. 35. - С. 324-330.

11. Таукешева Т. Д. Бюджетна децентралізація як чинник зміцнення місцевого самоврядуванняв Україні / Т. Д. Таукешева, Г. В. Даудова // Теорія та практика державного управління. - 2015. - Вип. 1. - С. 153-158.

12. Akai N., Sakata M. Fiscal Decentralization Contributes to Economic Growth: Evidence from State-Level Cross-Section Data for the United States // Journal of Urban Economics. 2002.

13. Oates W. E. Of the evolution of fi scal federalism: theory and institutions // National tax journal. - 2008. Vol. 61. - June. - P. 313-334.

14. Rodriguez-Pose A., Kroijer A. Fiscal Decentralization and Economic Growth in Central and Eastern Europe / LEQS. Paper No. 12/2009. URL: http://www.lse.ac.uk/europeanInstitute/LEQS\%20Discussion\%20Paper\%20Series/ LEQSPaper12.pdf.

15. Wallis J., Oates W. Decentralization in the Public Sector: An Empirical Study of State and Local Government // Fiscal Federalism: Quantitative Studies / Ed. by H. Rosen. Chicago: University of Chicago Press, 1988. P. 13-15.

16. Zhang T., Zou H.-F. Fiscal Decentralization, Public Spending, and Economic Growth in China // Journal of Public Economics. 1998. Vol. 67. Issue 2. P. 221-240. 